\title{
Cellular and Molecular Basis of Epithelial-Mesenchymal Transition in Renal Fibrosis
}

\author{
Yoshiyuki Morishita* and Eiji Kusano
}

Division of Nephrology, Department of Medicine, Jichi Medical University, Tochigi, Japan

\begin{abstract}
Regardless of the underlying etiology, tubulointerstitial fibrosis is a common mechanism in the progression of chronic kidney disease (CKD) to end-stage renal disease. Epithelial-mesenchymal transition (EMT) of renal tubular cells plays an important role in tubulointerstitial fibrosis. Transforming growth factor- $\beta_{1} / S_{\text {Sma }}$ and Mad protein (TGF- $\beta_{1} / \mathrm{Smad}$ ) is thought to be a main signaling pathway for EMT of renal tubular cells. Progressive renal disease is also characterized histologically by an interstitial infiltrate of mononuclear cells. The chemokines secreted from renal tubular cells can trigger integrin-dependent adhesion of circulating mononuclear cells that leads to infiltration at tubulointerstitial space. The direct interaction of integrin lymphocyte function-associated antigen 1(LFA-1: $\alpha_{\llcorner} \beta_{2}$ integrin) on mononuclear cells and its ligand, intracellular adhesion molecule-1(ICAM-1) on renal tubular epithelial cells, contributes to a part of the EMT of renal tubular cells.
\end{abstract}

\section{Introduction}

Regardless of the underlying etiology, tubulointerstitial fibrosis is a common mechanism in the progression of chronic kidney disease (CKD) to end-stage renal disease [1,2]. Epithelial-mesenchymal transition (EMT) of renal tubular cells, a process in which differentiated epithelial cells undergo transition to a fibroblast phenotype, plays an important role in renal fibrosis [3,4]. The cellular and molecular mechanism behind EMT has been increasingly understood as a result of basic and clinical studies in this field.

\section{Characterization of EMT}

EMT was originally described as an event for dispersing cells in vertebrate embryos [5]. EMT also has pivotal roles in cancer cells as a molecular mechanism for tumor invasion and metastasis [6-8]. EMT is a biological process in which an epithelial cell that interacts with basement membrane with its basal surface undergoes transition to a mesenchymal cell phenotype, which has enhanced migratory capacity and invasiveness and increased production of extracellular matrix [9]. This transition is characterized by loss of epithelial cell marker proteins such as E-cadherin, occludin and cytokeratin and acquisition of mesenchymal cell marker proteins such as $\alpha$-smooth muscle actin ( $a-S A M)$, vimentin, fibroblast-specific protein 1 (FSP1) and fibronectin (Figure 1) [9-11].

\section{EMT in renal fibrosis}

Evidence for the role of EMT of tubular cells in renal fibrosis is emerging. Fibroblasts are not abundant in normal kidney. Iwano et al. [12] reported the convincing evidence for EMT in vivo as a source of interstitial fibroblast. They showed 36\% of all FSP1-positive fibroblasts in interstitial space originated from renal proximal tubules after unilateral ureteral obstruction using genetically tagged proximal tubular cells [12]. In addition, several studies using a similar cell lineagetracing technique reported a substantial number of fibroblasts were derived from capillary endothelia which is a specialized type of epithelia by endothelial-to-mesenchymal transition [13,14]. These results strongly suggested that renal tubular epithelial cells and capillary endothelia migrated into interstitial space during EMT. In addition, the activation of originally resident fibroblasts and the accumulation of perivascular smooth muscle cells, pericytes and circulated fibrocytes were speculated to be associated with some portions of fibroblasts [15].

Several clinical studies utilizing human kidney biopsies suggested that EMT of tubular cells plays a role in the pathogenesis of renal

fibrosis [16-18]. Nishitani et al. [17] reported that FSP1 was detected in some tubular epithelial cells undergoing EMT as well as fibroblasts in areas showing severe interstitial fibrosis in renal biopsy specimens of IgA nephropathy patients [17]. Furthermore, FSP1 expression is directly correlated with serum creatinine and inversely correlated with estimated creatinine clearance [17]. Rastldi et al. [18] reported the

Epithelial Phenotype

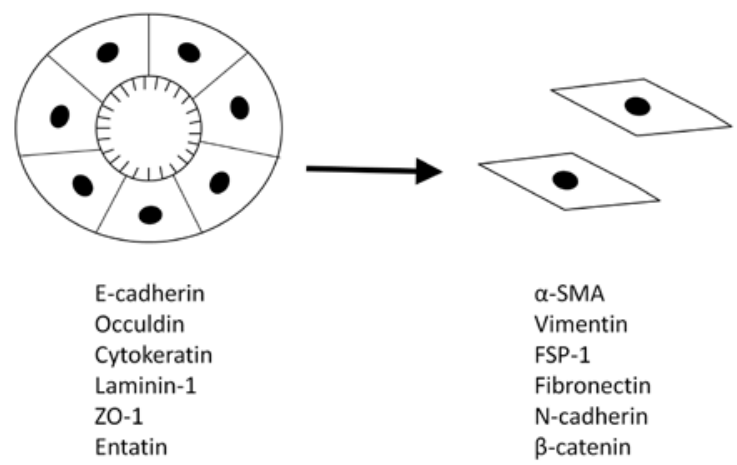

Figure 1: Epithelial-mesenchymal transition (EMT) of renal tubular cells. Epithelial cells that interacts with basement membrane with its basal surface undergoes transition to a mesenchymal cell phenotype. This transition is characterized by loss of epithelial cell marker proteins and acquisition of mesenchymal cell marker proteins. ZO-1: zonula occludens-1, $\alpha$-SMA: $\alpha$-smooth muscle actin, FSP1: fibroblast-specific protein 1

*Corresponding author: Y. Morishita, Division of Nephrology, Department of Medicine, Jichi Medical University, 3311-1, Yakushiji, Shimotsuke-city, Tochigi 3290498, Japan, Tel: 81-285-44-7346; Fax: 81-285-44-4869; E-mail: ymori@jichi.ac.jp

Received August 24, 2011; Accepted September 26, 2011; Published October 19,2011

Citation: Morishita Y, Kusano E (2011) Cellular and Molecular Basis of EpithelialMesenchymal Transition in Renal Fibrosis. J Nephrol Therapeutic S3:001. doi:10.4172/2161-0959.S3-001

Copyright: (c) Morishita $\mathrm{Y}$, et al. This is an open-access article distributed under the terms of the Creative Commons Attribution License, which permits unrestricted use, distribution, and reproduction in any medium, provided the original author and source are credited. 
expression of $\alpha$-SMA and vimentin on tubular epithelial cells in various renal diseases; however, they were not detected in tubular epithelial cells of normal kidney [18]. They also reported that about $10 \%$ of tubular cells lost epithelial proteins and these EMT feature changes were associated with serum creatinine and the degree of interstitial damage [18]. Hertig et al. [16] reported that de novo expression of vimentin of tubular epithelial cells in allograft kidney was significantly correlated with the progression of fibrosis.

There are rooms to discuss the extent of contribution of EMT for renal fibrosis. Although loss of epithelial markers and acquired mesenchymal markers are a feature of EMT, fibroblastic transition has been more difficult to define because most of these markers change are not specific for fibroblast because they are expressed in other cells as inflammatory cells and endothelial [19]. Furthermore, tubular epithelial cells and endothelial cells after stimulations may undergo partial EMT in which these cells only changed one or two phenotypic markers but not leave their local microenvironment $[11,16]$. Further studies will be required to investigate the EMT for renal fibrosis.

\section{Fibrogenic and antifibrogenic factors for EMT of renal tubular cells}

Accumulated evidence has revealed that EMT of renal tubular cells can be induced by a variety of molecules (Table 1).

\section{Transforming growth factor- $\beta$}

In $\mathrm{CKD}$, transforming growth factor- $\beta /$ Sma and Mad protein (TGF- $\beta /$ Smad) is thought to be a main signaling pathway for EMT of renal tubular cells [20-22]. Three TGF- $\beta$ isoforms (TGF- $\beta$ ${ }_{3}$ ) were identified in mammals [23-25]. Although it depends on the tissue, all three isoforms may be involved in EMT. TGF- $\beta_{1}$ is the most extensively studied in EMT of renal tubular cells [26]. TGF- $\beta_{1}$ mainly induces phosphorylation and activation of Smad2 and Smad3 via transmembrane TGF- $\beta$ receptor. Then, phosphorylated Smad2 and Smad3 heterooligomerize with Smad4 and translocate into the nucleus, where they regulate the various genes that mediate EMT $[27,28]$. TGF- $\beta_{1}$ also activates Smad-independent signaling, which plays a role for EMT, such as through extracellular signal-regulated kinase (ERK) 1/2, p-38 mitogen-activated protein kinase (p38 MAPK) and phosphatidylinositol-3-kinase/Akt [11]. The activation of ERK pathway is required for TGF- $\beta_{1}$-induced EMT of renal tubular cells and long-term ERK1/2 activation is an important mechanism involved in the EMT of renal tubular cells $[29,30]$.

\section{Other fibrogenic and antifibrogenic factors}

Integrin-linked kinase (ILK) is a serine/threonine protein kinase that interacts with cytoplasmic domains of $\beta$-integrins and regulates the integrin signals. ILK regulates EMT by its protein kinase activity $[31,32]$. Wnt induces dephosphorylation of $\beta$-catenin as a result

\begin{tabular}{|c|c|}
\hline Fibrogenic factors & Antifibrogenic factors \\
\hline TGF- $\beta_{1}$ & HGF \\
\hline ILK & BMP-7 \\
\hline Wnt & IGF-1 \\
\hline LEF1 & VitaminD \\
\hline CTFG & Statin \\
\hline Angiotensin II & \\
\hline ET-1 & \\
\hline
\end{tabular}

TGF- $\beta_{1}$ : transforming growth factor- $\beta_{,}$, ILK: Integrin-linked kinase, LEF-1: T cell factor/lymphoid enhancer-binding factor-1, CTFG: connective tissue growth factor, ET-1: endothelin-1, IL-1: interleukin-1, HGF: hepatocyte growth factor, IGF-1 insulin-like growth factor-1, BMP-7: bone morphogenic protein-7.

Table1: The fibrogenic and antifibrogenic factors for EMT of renal tubular cell. of activation of its downstream signaling pathway. This stabilizes $\beta$-catenin translocation into the nucleus, where it binds to $\mathrm{T}$ cell factor/lymphoid enhancer-binding factor-1 (LEF1) to regulate the various genes that mediate EMT $[33,34]$. Connective tissue growth factor (CTFG) is a downstream mediator of TGF- $\beta$ signaling. CTFG binds to its receptor. CTGF induces fibroblast proliferation and matrix protein synthesis $[35,36]$. Angiotensin II is reported to increase TGF- $\beta$ in renal tubular cells. Several studies demonstrated that the block of angiotensin II by angiotensin converting enzyme inhibitor attenuated tubulointerstitial fibrosis with reduced TGF- $\beta_{1}$ production $[37,38]$ In addition, several studies demonstrated that angiotensin II might have a direct effect on collagen gene expression [39,40]. These results suggested that angiotensin II may have fibrogenic effects independent of the TGF- $\beta_{1}$ pathway. Endothelin-1 (ET-1) is most abundant in kidney among the three isoforms that have been identified in mammals. ET-1 up-regulates TGF- $\beta$ expression [26]. In addition, ET-1 may have a direct effect to promote renal fibrosis by stimulating matrix synthesis and decreasing collagenase activity [26,41,42]. Interleukin-1 (IL-1) is a proinflammatory cytokine that has the potential to increase proliferation of fibroblasts and matrix production [43].

\section{Antifibrogenic factors}

Hepatocyte growth factor (HGF) has been reported to attenuate tubulointerstitial fibrosis associated with reduction of platelet-derived growth factor and TGF- $\beta_{1}$ in nephrotic mouse model [44,45]. Bone morphogenic protein-7 (BMP-7) directly attenuates TGF- $\beta_{1} / \mathrm{Smad}$ signaling and prevents EMT of renal tubular cells [46,47]. Insulin-like growth factor-1 (IGF-1) has been reported to reduce tubulointerstitial collagen accumulation in obstructive uropathy mouse model [48]. Vitamin D analogue and statin contribute to suppress EMT of renal tubular cells at least to some extent $[49,50]$.

\section{Role of mononuclear cells for EMT on renal tubular cells}

Progressive renal disease is characterized histologically by an interstitial infiltrate of mononuclear cells. Most of these infiltrated cells have migrated from the circulation through peritubular capillary endothelium into the interstitial space. The locally secreted chemokines can trigger integrin-dependent adhesion of circulating leukocytes that leads to infiltration [51-54]. The stimulus for this migration is thought to be chemotactic cytokines that are secreted from tubular cells. Several studies have characterized the expression pattern of chemokines in animal models of tubulointerstitial disease [55-57]. They demonstrated that various chemokine such as chemokine ligand 2 (CCL2), chemokine ligand 3 (CCL3), chemokine ligand 4 (CCL4) and chemokine ligand 5 (CCL5) are expressed only in the diseased compartment of the kidney and renal chemokine expression has been found to correlate with the leukocyte accumulation area and renal damage [55-58]. The blocking of CCL2 activity by antibodies or antisense against CCL2 reduced the infiltration of mononuclear cells in several murine nephrotoxic nephritis models $[59,60]$. CCL2 null mice given nephrotoxic serum showed reduced tubulointerstitial injury [61]. CCL5 antagonist reduced proteinuria, $\mathrm{T}$ cell and macrophage infiltration in nephrotoxic serum-induced nephritis mouse model [62]. These studies strongly suggest that infiltrated mononuclear cells have pivotal roles in the progression of renal tubular damage leading to renal fibrosis; however, the mechanism of how those infiltrated mononuclear cells contribute to renal fibrosis remains to be elucidated. Recently, we reported that the interaction of integrin lymphocyte function-associated antigen 1(LFA-1: $\alpha_{1} \beta_{2}$ integrin) on peripheral blood mononuclear cells (PBMCs) and intracellular adhesion molecules-1 (ICAM-1) on renal tubular epithelial cells accelerated TGF- $\beta_{1}$-induced EMT of renal tubular epithelial cells [63]. LFA-1 is the predominant integrin on leukocytes and an important molecule in firm adhesion and migration 
of leukocytes to inflammatory sites [64,65]. LFA-1 also plays pivotal roles as a signal transduction molecule by binding its ligand, ICAM$1[66,67]$. Normally, LFA-1 is expressed in a low-affinity state for its ligand and, thus, cells do not make unnecessary adhesive contacts while in circulation $[68,69]$. The affinity of LFA-1 for ICAM-1 is mediated by a conformational change of LFA-1 $[68,69]$. They play essential roles in most inflammatory reactions $[68,69]$. ICAM- 1 has been reported to be expressed on renal tubular epithelial cells and its expression was found to be associated with the infiltration of leukocytes in CKD [70,71]. We reported that renal tubular epithelial cells stimulated with TGF- $\beta_{1}$ induced conformational activation of LFA-1 on PBMCs by increasing CXCL12, which was reported to activate LFA-1 on both monocytes and lymphocytes $[63,72-76]\}$. Then, the direct interaction of LFA-1 on PBMCs and ICAM-1 on renal tubular epithelial cells activated ERK1/2 signaling to accelerate the part of EMT of renal tubular epithelial cells induced by TGF- $\beta_{1}$ [63].

\section{Acknowledgement}

This work was in part supported by grants from The Kidney Foundation, Japan (JFL 11-3), and Jichi Medical University Young Investigator Award.

\section{References}

1. Nath KA (1992) Tubulointerstitial changes as a major determinant in the progression of renal damage.Am J Kidney Dis 20: 1-17.

2. Becker GJ, Hewitson TD (2000) The role of tubulointerstitial injury in chronic renal failure. Curr Opin Nephrol Hypertens 9: 133-138.

3. Thiery JP, Sleeman JP (2006) Complex networks orchestrate epithelialmesenchymal transitions. Nat Rev Mol Cell Biol 7: 131-142.

4. Zeisberg M, Kalluri R (2004) The role of epithelial-to-mesenchymal transition in renal fibrosis. J Mol Med 82: 175-181.

5. Hay ED (1995) An overview of epithelio-mesenchymal transformation. Acta Anat (Basel) 154: 8-20.

6. Wang F, Wang HW, Lu DR, Xue JL, Zhang X (2003) Vesicular stomatitis virus G-protein retrovector mediated a herpes simplex virus thymidine kinase gene transduction and expression in the human retinal pigment epithelial cells. Zhonghua Yan Ke Za Zhi 39: 201-205.

7. Fujii T, Hogg JC, Keicho N, Vincent R, Van Eeden SF, et al. (2003) Adenoviral E1A modulates inflammatory mediator expression by lung epithelial cells exposed to PM10. Am J Physiol Lung Cell Mol Physiol 284: 290-297.

8. Janda E, Lehmann K, Killisch I, Jechlinger M, Herzig M, et al. (2002) Ras and TGF[beta] cooperatively regulate epithelial cell plasticity and metastasis: dissection of Ras signaling pathways. J Cell Biol 156: 299-313.

9. Kalluri R, Neilson EG (2003) Epithelial-mesenchymal transition and its implications for fibrosis. J Clin Invest 112: 1776-1784.

10. Yang J, Dai C, Liu Y (2005) A novel mechanism by which hepatocyte growth factor blocks tubular epithelial to mesenchymal transition. J Am Soc Nephrol 16: $68-78$.

11. Liu $Y$ (2010) New insights into epithelial-mesenchymal transition in kidney fibrosis. J Am Soc Nephrol 21: 212-222.

12. Iwano M, Plieth D, Danoff TM, Xue C, Okada H, et al. (2002) Evidence that fibroblasts derive from epithelium during tissue fibrosis. J Clin Invest 110: 341 350

13. Zeisberg EM, Potenta SE, Sugimoto H, Zeisberg M, Kalluri R (2008) Fibroblasts in kidney fibrosis emerge via endothelial-to-mesenchymal transition. J Am Soc Nephrol 19: 2282-2287.

14. Li J, Qu X, Bertram JF (2009) Endothelial-myofibroblast transition contributes to the early development of diabetic renal interstitial fibrosis in streptozotocininduced diabetic mice. Am J Pathol 175: 1380-1388.

15. Liu Y (2004) Epithelial to mesenchymal transition in renal fibrogenesis: pathologic significance, molecular mechanism, and therapeutic intervention. J Am Soc Nephrol 15: 1-12

16. Hertig A, Anglicheau D, Verine J, Pallet N, Touzot M, et al. (2008) Early epithelial phenotypic changes predict graft fibrosis. J Am Soc Nephrol 19: 1584-1591.

17. Nishitani Y, Iwano M, Yamaguchi Y, Harada K, Nakatani K, et al. (2005) Fibroblast-specific protein 1 is a specific prognostic marker for renal survival in patients with IgAN. Kidney Int 68: 1078-1085.
18. Rastaldi MP, Ferrario F, Giardino L, Dell'Antonio G, Grillo C, et al. (2002) Epithelial-mesenchymal transition of tubular epithelial cells in human renal biopsies. Kidney Int 62: 137-146.

19. Willis BC, Borok Z (2007) TGF-beta-induced EMT: mechanisms and implications for fibrotic lung disease. Am J Physiol Lung Cell Mol Physiol 293 L525-534

20. Kopp JB, Factor VM, Mozes M, Nagy P, Sanderson N, et al. (1996) Transgenic mice with increased plasma levels of TGF-beta 1 develop progressive renal disease. Lab Invest 74: 991-1003.

21. Strutz FM (2009) EMT and proteinuria as progression factors. Kidney Int 75 475-481.

22. Phanish MK, Wahab NA, Colville-Nash P, Hendry BM, Dockrell ME (2006) The differential role of Smad2 and Smad3 in the regulation of pro-fibrotic TGFbeta1 responses in human proximal-tubule epithelial cells. Biochem J 393: 601-607.

23. Zavadil J, Bottinger EP (2005) TGF-beta and epithelial-to-mesenchyma transitions. Oncogene 24: 5764-5774.

24. Kaneto H, Morrissey J, Klahr S (1993) Increased expression of TGF-beta 1 mRNA in the obstructed kidney of rats with unilateral ureteral ligation. Kidney Int 44: 313-321.

25. Shirakihara T, Horiguchi K, Miyazawa K, Ehata S, Shibata T, et al. (2011) TGFbeta regulates isoform switching of FGF receptors and epithelial-mesenchymal transition. EMBO J 30: 783-795.

26. Eddy AA (2000) Molecular basis of renal fibrosis. Pediatr Nephrol 15: 290-301.

27. Bottoms SE, Howell JE, Reinhardt AK, Evans IC, McAnulty RJ (2010) Tgf-Beta isoform specific regulation of airway inflammation and remodelling in a murine model of asthma. PLoS One 5: e9674.

28. Jobling Al, Wan R, Gentle A, Bui BV, McBrien NA (2009) Retinal and choroida TGF-beta in the tree shrew model of myopia: isoform expression, activation and effects on function. Exp Eye Res 88: 458-466.

29. Schramek H (2002) MAP kinases: from intracellular signals to physiology and disease. News Physiol Sci 17: 62-67.

30. Schramek H, Feifel E, Marschitz I, Golochtchapova N, Gstraunthaler G, et al. (2003) Loss of active MEK1-ERK1/2 restores epithelial phenotype and morphogenesis in transdifferentiated MDCK cells. Am J Physiol Cell Physio 285: 652-661.

31. Schabort EJ, van der Merwe M, Loos B, Moore FP, Niesler CU (2009) TGF beta's delay skeletal muscle progenitor cell differentiation in an isoformindependent manner. Exp Cell Res 315: 373-384.

32. Cho ML, Yoon BY, Ju JH, Jung YO, Jhun JY, et al. (2007) Expression of CCR2A, an isoform of MCP-1 receptor, is increased by MCP-1, CD40 ligand and TGF-beta in fibroblast like synoviocytes of patients with RA. Exp Mol Med 39: 499-507.

33. Ask K, Bonniaud P, Maass K, Eickelberg O, Margetts PJ, et al. (2008) Progressive pulmonary fibrosis is mediated by TGF-beta isoform 1 but not TGF-beta3. Int J Biochem Cell Biol 40: 484-495.

34. Ronty MJ, Leivonen SK, Hinz B, Rachlin A, Otey CA, et al. (2006) Isoformspecific regulation of the actin-organizing protein palladin during TGF-beta1induced myofibroblast differentiation. J Invest Dermatol 126: 2387-2396.

35. Jung ST, Moon ES, Seo HY, Kim JS, Kim GJ, et al. (2005) Expression and significance of TGF-beta isoform and VEGF in osteosarcoma. Orthopedics 28 : 755-760.

36. Sarkar DK, Chaturvedi K, Oomizu S, Boyadjieva NI, Chen CP (2005) Dopamine, dopamine D2 receptor short isoform, transforming growth facto (TGF)-beta1, and TGF-beta type II receptor interact to inhibit the growth of pituitary lactotropes. Endocrinology 146: 4179-4188.

37. Han F, Adams CS, Tao Z, Williams CJ, Zaka R, et al. (2005) Transforming growth factor-beta1 (TGF-beta1) regulates ATDC5 chondrogenic differentiation and fibronectin isoform expression. J Cell Biochem 95: 750-762.

38. Dhandapani KM, Wade MF, Mahesh VB, Brann DW (2002) Basic fibroblas growth factor induces TGF-beta release in an isoform and glioma-specific manner. Neuroreport 13: 239-241.

39. Franchi A, Benvenuti S, Masi L, Malentacchi C, Arganini L, et al. (2001) TGFbeta isoform and receptor expression in giant cell tumor and giant cell lesions of bone. Appl Immunohistochem Mol Morphol 9: 170-175

40. Janji B, Melchior C, Vallar L, Kieffer N (2000) Cloning of an isoform of integrinlinked kinase (ILK) that is upregulated in HT-144 melanoma cells following TGF-beta1 stimulation. Oncogene 19: 3069-3077. 
41. Foitzik K, Paus R, Doetschman T, Dotto GP (1999) The TGF-beta2 isoform is both a required and sufficient inducer of murine hair follicle morphogenesis. Dev Biol 212: 278-289.

42. Mozes MM, Hodics T, Kopp JB (1999) Isoform specificity of commerciallyavailable anti-TGF-beta antibodies. J Immunol Methods 225: 87-93.

43. Bobik A, Agrotis A, Kanellakis P, Dilley R, Krushinsky A, et al. (1999) Distinct patterns of transforming growth factor-beta isoform and receptor expression in human atherosclerotic lesions. Colocalization implicates TGF-beta in fibrofatty lesion development. Circulation 99: 2883-2891.

44. Persson U, Izumi H, Souchelnytskyi S, Itoh S, Grimsby S, et al. (1998) The L45 loop in type I receptors for TGF-beta family members is a critical determinant in specifying Smad isoform activation. FEBS Lett 434: 83-87.

45. Stern PH, Krieger NS, Nissenson RA, Williams RD, Winkler ME, et al. (1985) Human transforming growth factor-alpha stimulates bone resorption in vitro. J Clin Invest 76: 2016-2019.

46. Fahey MS, Paterson IC, Stone A, Collier AJ, Heung YL, et al. (1996) Dysregulation of autocrine TGF-beta isoform production and ligand responses in human tumour-derived and Ha-ras-transfected keratinocytes and fibroblasts. Br J Cancer 74: 1074-1080

47. Suzuki A, Shioda N, Maeda T, Tada M, Ueno N (1994) Cloning of an isoform of mouse TGF-beta type II receptor gene. FEBS Lett 355: 19-22.

48. Peracchia F, Ferrari G, Poggi A, Rotilio D (1991) IL-1 beta-induced expression of PDGF-AA isoform in rabbit articular chondrocytes is modulated by TGF-beta 1. Exp Cell Res 193: 208-212.

49. Brissenden JE, Derynck R, Francke U (1985) Mapping of transforming growth factor alpha gene on human chromosome 2 close to the breakpoint of the Burkitt's lymphoma t(2;8) variant translocation. Cancer Res 45: 5593-5597.

50. Derynck R, Jarrett JA, Chen EY, Eaton DH, Bell JR, et al. (1985) Human transforming growth factor-beta complementary DNA sequence and expression in normal and transformed cells. Nature 316: 701-705.

51. Buyon JP, Abramson SB, Philips MR, Slade SG, Ross GD, et al. (1988) Dissociation between increased surface expression of gp165/95 and homotypic neutrophil aggregation. J Immunol 140: 3156-3160.

52. Bargatze RF, Butcher EC (1993) Rapid G protein-regulated activation event involved in lymphocyte binding to high endothelial venules. J Exp Med 178: 367-372.

53. Dwinell MB, Ogawa H, Barrett KE, Kagnoff MF (2004) SDF-1/CXCL12 regulates CAMP production and ion transport in intestinal epithelial cells via CXCR4. Am J Physiol Gastrointest Liver Physiol 286: 844-850.

54. Tanaka Y, Adams DH, Hubscher S, Hirano H, Siebenlist U, et al. (1993) T-cell adhesion induced by proteoglycan-immobilized cytokine MIP-1 beta. Nature 361: 79-82.

55. Tang WW, Feng L, Mathison JC, Wilson CB (1994) Cytokine expression, upregulation of intercellular adhesion molecule-1, and leukocyte infiltration in experimental tubulointerstitial nephritis. Lab Invest 70: 631-638.

56. Ou ZL, Natori Y (1999) Gene expression of CC chemokines in experimental acute tubulointerstitial nephritis. J Lab Clin Med 133: 41-47.

57. Segerer S, Nelson PJ, Schlondorff D (2000) Chemokines, chemokine receptors, and renal disease: from basic science to pathophysiologic and therapeutic studies. J Am Soc Nephrol 11: 152-176.

58. Haberstroh U, Stilo K, Pocock J, Wolf G, Helmchen U, et al. (1998) L-arginine suppresses lipopolysaccharide-induced expression of RANTES in glomeruli. J Am Soc Nephrol 9: 203-210.

59. Fujinaka H, Yamamoto T, Takeya M, Feng L, Kawasaki K, et al. (1997) Suppression of anti-glomerular basement membrane nephritis by administration of anti-monocyte chemoattractant protein-1 antibody in WKY rats. J Am Soc Nephrol 8: 1174-1178.

60. Tesch GH, Schwarting A, Kinoshita K, Lan HY, Rollins BJ, et al. (1999) Monocyte chemoattractant protein-1 promotes macrophage-mediated tubula injury, but not glomerular injury, in nephrotoxic serum nephritis. J Clin Invest 103: 73-80.

61. Okada H, Moriwaki K, Kalluri R, Imai H, Ban S, et al. (2000) Inhibition of monocyte chemoattractant protein-1 expression in tubular epithelium attenuates tubulointerstitial alteration in rat Goodpasture syndrome. Kidney In 57: 927-936.

62. Lloyd CM, Minto AW, Dorf ME, Proudfoot A, Wells TN, et al. (1997) RANTES and monocyte chemoattractant protein-1 (MCP-1) play an important role in the inflammatory phase of crescentic nephritis, but only MCP-1 is involved in crescent formation and interstitial fibrosis. J Exp Med 185: 1371-1380.

63. Morishita Y, Watanabe M, Nakazawa E, Ishibashi K, Kusano E (2011) The Interaction of LFA-1 on Mononuclear Cells and ICAM-1 on Tubular Epithelial Cells Accelerates TGF-beta1-Induced Renal Epithelial-Mesenchymal Transition. PLoS One 6: 23267

64. Lu C, Shimaoka M, Salas A, Springer TA (2004) The binding sites fo competitive antagonistic, allosteric antagonistic, and agonistic antibodies to the I domain of integrin LFA-1. J Immunol 173: 3972-3978.

65. Gahmberg CG, Tolvanen M, Kotovuori P (1997) Leukocyte adhesion--structure and function of human leukocyte beta2-integrins and their cellular ligands. Eur J Biochem 245: 215-232

66. Shimizu Y, van Seventer GA, Horgan KJ, Shaw S (1990) Roles of adhesion molecules in T-cell recognition: fundamental similarities between four integrins on resting human T cells (LFA-1, VLA-4, VLA-5, VLA-6) in expression, binding, and costimulation. Immunol Rev 114: 109-143.

67. Van Seventer GA, Shimizu Y, Horgan KJ, Shaw S (1990) The LFA-1 ligand ICAM-1 provides an important costimulatory signal for $T$ cell receptor-mediated activation of resting T cells. J Immunol 144: 4579-4586.

68. Carman CV, Springer TA (2003) Integrin avidity regulation: are changes in affinity and conformation underemphasized? Curr Opin Cell Biol 15: 547-556.

69. Kinashi T, Katagiri K (2004) Regulation of lymphocyte adhesion and migration by the small GTPase Rap1 and its effector molecule, RAPL. Immunol Lett 93 : $1-5$

70. Tomino Y, Ohmuro H, Kuramoto T, Shirato I, Eguchi K, et al. (1994) Expression of intercellular adhesion molecule-1 and infiltration of lymphocytes in glomerul of patients with IgA nephropathy. Nephron 67: 302-307.

71. Muller GA, Markovic-Lipkovski J, Muller CA (1991) Intercellular adhesion molecule-1 expression in human kidneys with glomerulonephritis. Clin Nephro 36: 203-208

72. Weber C, Alon R, Moser B, Springer TA (1996) Sequential regulation of alpha 4 beta 1 and alpha 5 beta 1 integrin avidity by CC chemokines in monocytes: implications for transendothelial chemotaxis. J Cell Biol 134: 1063-1073.

73. Chan JR, Hyduk SJ, Cybulsky MI (2001) Chemoattractants induce a rapid and transient upregulation of monocyte alpha4 integrin affinity for vascular cell adhesion molecule 1 which mediates arrest: an early step in the process of emigration. J Exp Med 193: 1149-1158

74. Lloyd AR, Oppenheim JJ, Kelvin DJ, Taub DD (1996) Chemokines regulate $T$ cell adherence to recombinant adhesion molecules and extracellular matrix proteins. J Immunol 156: 932-938.

75. Soede RD, Zeelenberg IS, Wijnands YM, Kamp M, Roos E (2001) Stromal cell-derived factor-1-induced LFA-1 activation during in vivo migration of T cell hybridoma cells requires $\mathrm{Gq} / 11$, RhoA, and myosin, as well as $\mathrm{Gi}$ and $\mathrm{Cdc} 42$. J Immunol 166: 4293-4301.

76. Peled A, Kollet O, Ponomaryov T, Petit I, Franitza S, et al. (2000) The chemokine SDF-1 activates the integrins LFA-1, VLA-4, and VLA-5 on immature human CD34(+) cells: role in transendothelial/stromal migration and engraftment of NOD/SCID mice. Blood 95: 3289-3296. 